\title{
Prioritising Marketing Activities in Different Types of Marketing Functions
}

Martensen, Anne; Mouritsen, Jan

\author{
Document Version \\ Accepted author manuscript \\ Published in: \\ Total Quality Management \& Business Excellence
}

DOI:

10.1080/14783363.2015.1135726

Publication date:

2017

License

Unspecified

Citation for published version (APA):

Martensen, A., \& Mouritsen, J. (2017). Prioritising Marketing Activities in Different Types of Marketing Functions. Total Quality Management \& Business Excellence, 28(11-12), 1264-1284.

https://doi.org/10.1080/14783363.2015.1135726

Link to publication in CBS Research Portal

\section{General rights}

Copyright and moral rights for the publications made accessible in the public portal are retained by the authors and/or other copyright owners and it is a condition of accessing publications that users recognise and abide by the legal requirements associated with these rights.

\section{Take down policy}

If you believe that this document breaches copyright please contact us (research.lib@cbs.dk) providing details, and we will remove access to the work immediately and investigate your claim.

Download date: 26. Apr. 2023

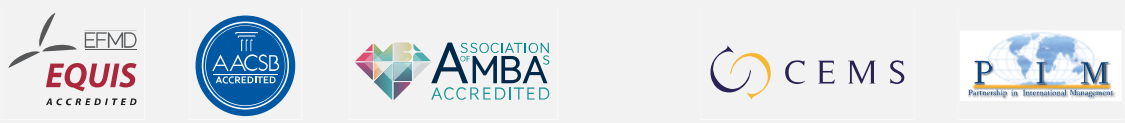




\section{Prioritising Marketing Activities in Different Types of Marketing Functions}

Anne Martensen and Jan Mouritsen

Journal article (Post print version)

Cite: Prioritising Marketing Activities in Different Types of Marketing Functions. / Martensen, Anne; Mouritsen, Jan. I: Total Quality Management \& Business Excellence, २०16.

This is an Accepted Manuscript of an article published by Taylor \& Francis in Total Quality Management \& Business Excellence on 16 February २016, available online: http://www.tandfonline.com/10.1080/14783363.2015.1135726

Uploaded to Research@CBS: May २०17 


\section{Prioritizing marketing activities in different types of marketing functions}

Anne Martensen, Associate Professor, Department of Marketing, Copenhagen Business School,

Solbjerg Plads 3, 2000 Frederiksberg, Denmark, +45 3815 2118, am.marketing@ cbs.dk.

Jan Mouritsen, Professor, Department of Operations Management, Copenhagen Business School,

Solbjerg Plads 3, 2000 Frederiksberg, Denmark, +45 3815 2420,jm.om@cbs.dk. 


\begin{abstract}
Marketing functions differ in how they practice marketing roles. The purpose of this article is to differentiate between marketing functions that practice marketing roles in a particular manner and then study how these different types of marketing functions differ with regard to the marketing roles' effect on business performance and top management's respect.

An empirical survey identifies four types of marketing functions: (1) the broad-spectrum; (2) the hesitant; (3) the traditional; and (4) the market-creating. Findings show that for each of the four types, the effect of investing in a particular role varies: all roles are not equally important to practice. Moreover, all roles are not equally important to all marketing functions, but depend on the marketing function's unique starting point. Since marketing functions differ, relevant investments in marketing roles also differ, making it beneficial to prioritize them. However, management dilemmas existbecause to gain top management respect the marketing functions may have to perform roles that will not improve business performance.
\end{abstract}

Keywords: Prioritizing marketing investment, Types of marketing functions, Business performance, Top management's respect, Structural equation modeling, On-line survey.

Financial disclosure: Financial support for data collection was provided by Megafon A/S and DEA, Denmark. 


\section{Introduction}

What should a marketing function (MF) do to increase its performance? It has been difficult to demonstrate how the MF adds value to the company and contributes to business performance $(\mathrm{BP}=$ market results and financial performance) (e.g., Homburg, Vomberg, Enke and Grimm 2014; O'Sullivan and Abela 2007; Stewart 2009; Webster, Malter and Ganesan 2005). 73 percent of CEOs in a recent study agree with the statement that marketers "are always asking for more money, but can rarely explain how much incremental business this money will generate" (Gordon and Perrey 2015, p. 30). 57 percent of senior corporate marketers do not base their budgets on any profitability assessments (Rogers and Sexton 2012). This reduces MFs' credibility vis-a-vis top management and makes MFs' path to increased value ambiguous (e.g., Bharadwaj, Varadarajan, and Fahy 1993; Hunt and Morgan 1995; Moorman and Rust 1999). Current knowledge is surprisingly sketchy about how MFs improve BP and respect among top management. This is emphasized by Webster et al. (2005, p. 38): "it is hard to win budgetary support for marketing if it remains an ambiguous concept with unclear responsibilities and makes an uncertain contribution to the company's financial performance" (see also Bolton 2006, Srivastava et al. 1998). It is challenging to evaluate the influence on BP and respect among top management of investments in marketing, because MFs vary as to how they compose, organize and practice their marketing activities and roles (Martensen and Mouritsen 2014). Due to this variability investing in a particular role will hardly have similar marginal effects in all MF. Existing research often studies what is general to all MFs (Verhoef and Leeflang, 2009; Moorman and Rust, 1998).

However, the average effect may explain too little and may not be very helpful in understanding how variability in practicing the marketing roles creates different effects. Attention to difference is an interesting managerial strategy. MFs' different starting points imply that they may benefit from 
very different strategies to earn respect among top management and to contribute to BP. Hence, managers need to be concerned with specific effects rather than general ones.

To improve knowledge of the effects of variability in practicing marketing roles the purpose of this study is to: (1) find types of MF that put similar effort into a generic set of marketing roles; (2) investigate how these types of MFs differ with regard to marketing roles' marginal effects on BP and respect among top management; and (3) prioritize the marketing roles to invest in within each type of MF.

This research contributes by showing that MFs starting point differs and therefore that their decisions about how to increase their performance also differ. Not all roles are equally important but depend on the specific type of $\mathrm{MF}$ and the targeted effects (market results, financial performance and/or top management's respect). This research also contributes by showing that large variation exists in how the individual role affects top management's respect and BP and whether this effect is positive or negative. The roles' effect and priority depends on the type of MF and therefore they will benefit most from investing in different roles. The MF's decisions depend on what type it is. This insight may help MF to play different roles in organizations and to decide which roles to invest in to develop their future profile.

We structure the rest of this article as follows: We present our conceptual model of how generic roles of the MF generally influence top management's respect and BP. We then propose that MF can be differentiated and grouped into types of MF according to how they practice generic marketing roles, i.e., based on variations in their effort on these marketing roles. Next we propose that such variation influences how different types of MF create effect in regard to BP and top management's respect. Then, we discuss the data collection procedure, sample, measurement scales, cluster technique used for grouping the MF into types, and technique for estimating the conceptual model. In the empirical results we characterize the different types of MF, discuss how their 
variation in effort results in different effects and how this makes it possible for each type of MF to prioritize their investments in the marketing roles. Finally, we discuss how roles with very different (positive/negative) effects generate management dilemmas and challenges because to gain top management respect the MF's may have to do things that will not help the firm's development in the market.

\section{Literature review and development of framework}

\section{Focus of previous research}

Research on MFs' activities has addressed three issues. One issue concerns how activities can be grouped into generic roles and capabilities reflecting general ways of doing things (e.g. Day 1994; Lehman 1997; Martensen and Mouritsen 2014; Moorman and Rust 1999; O'Sullivan og Abdela 2007; Srivastava et al. 1999; Verhoef and Leeflang 2009; Vorhies and Morgan 2005). A second issue concerns the organization of the roles and capabilities (see, e.g., Day 1994; Martensen and Mouritsen 2014; Moorman and Rust 1999; O'Sullivan og Abdela 2007; Srivastava et al. 1999; Verhoef and Leeflang 2009; Vorhies and Morgan 2005). The third issue concerns the influence of MF on BP (see, e.g., Martensen and Mouritsen 2014; Moorman and Rust 1999; Ramaswami et al. 2004; Srivastava et al. 1999; Verhoef and Leeflang 2009; O'Sullivan og Abdela 2007; Vorhies and Morgan 2005).

\section{Roles}

Recent research has been concerned to identify the various ways in which MF's roles, the bundles of activities that it performs, or its capabilities, the bundle of activities that it can perform, can be differentiated. Roles and capabilities are both bundles of activities that mark a MF with a distinction. Typically this distinction can take the form of core areas such as marketing strategy and implementation (little $\mathrm{m}$ ) or of broader and facilitating roles such as cross-functional coordination 
and participation in innovation (big M) (Day 1994, 2011; Moorman and Rust 1999; Srivastava et al. 1998; O'Sullivan and Abela 2007; Han et al. 1998; Lehmann 1997; Verhoef and Leeflang 2009). Moorman and Rust (1999) focus on the interaction between MFs and other departments (i.e. big M) but not much on classical (little m) roles. Verhoef and Leeflang (2009) study both little m and big $\mathrm{M}$ roles and relate them to MF's relative power, its respect in the boardroom and its decision influence; but not to its direct influence on BP.

A number of studies directs attention to the variations among MFs. Day (1994) suggest that MF may be involved in three generic processes: outside-in processes (little m), inside-out processes (big M) and spanning processes (big M). Ramaswami, Bhargava, and Srivastava (2004) suggest then MF to be involved in new product development (NPD), supply chain management (SCM) and customer relationship management (CRM). Lehman (1997) suggests four processes: CRM, SCM, NPD and information marketing research, where two are related to big $\mathrm{M}$, one to little $\mathrm{m}$ and one to market insight. But again, no evidence of the roles' impact on BP is reported. Srivastava, Fahey, and Christensen (2001) identify a series of indirect activities such as HRM and cross-functional coordination and Han, Kim, and Srivastava (1998) focus on innovation and these studies lack insight into the roles' effect on BP (see also O'Sullivan and Abdela 2007). These studies suggest a differentiation of what MFs do and what is important in organisations and indicate that they may do different things but they suggests little about the conditions favouring attention to the three processes.

Hence, previous research has differentiated what MFs may be concerned to do. MFs can therefore develop their profile: it may play different roles in organisations. Yet, these studies are not very helpful in explaining how this potential variability brings different effects.

The present study explores how different MFs produce effects and how they can make decisions to increase their performance. It starts from Martensen and Mouritsen's (2014) study which has 
identified seven generic roles, organized them in four dimensions and empirically tested and validated their relationship to BP. These findings are directly relevant for the purpose of this study. The generic roles and their organization are as follows:

Little m: These roles are internal to the MF (see MSI 1996, p. 6)) and can autonomously be managed and influenced by the MF. The roles require specialist knowledge in core marketing to be planned and implemented appropriately: (1) marketing implementation (PR, communication and marketing plans) and (2) marketing strategy (prioritizing segments, acquisition and retention of customers).

Big M: These roles require the MF's collaboration with other functional areas and external partners (see MSI 1996, p. 6). Big M roles do not necessarily require specialist knowledge within core marketing: (3) Innovation (business cases for new products, business relationships) and (4) Cross-functional coordination (link to other functional areas).

Market insight: (5) Measurement of effectiveness (Key Performance Indicators (KPI)) and (6) Production of market intelligence (SWOT, new ideas from many areas);

HRM marketing: (7) HRM (recruiting, maintaining and development of employees).

Using the results from Martensen and Mouritsen's (2014) study, it can be proposed that:

P1: MFs can be divided meaningfully into types according to their effort on seven generic marketing roles.

\section{Variations in practising marketing roles}

Previous research often assumes that all marketing roles are near to equally important (see e.g. Day 1994; Lehman 1997). However, it is an unlikely assumption and it is unfortunate as the composition, complementarity and relationship of and between roles provide the specific MF with identity and orientation (Moorman and Slotegraaf 1999; Morgan, Slotegraaf, and Vorhies 2009) and requires the MF to be managed (Webster 2005). Hence: 
P2: There is variation in how MFs perform marketing roles that are carried out with different intensities across MFs.

\section{Organizing the roles and their influence on business performance and top management's respect}

There may be many different types of effects of the differentiation between MFs. One almost obvious difference is performance effect, i.e. the effect of different types of MFs on the financial and market performance of firms (Martensen and Mouritsen 2014). Another, more discussed, effect is on top management's respect for MF (see Verhoef and Leeflang 2009; Webster et al. 2005; Nath and Mahajan 2008), the relationship between MF and other organizational functions (Brown et al., 2005; Schultz 2005; Verhoef and Leeflang 2009; Webster, Malter and Ganesan 2005) and the effect of external conditions on the company's environment, corporate strategies and institutional factors (Homburg, Workman and Krohmer 1999).

It is likely that there is some relationship between BP and top management's respect but this needs not to be strong. Some (e.g., Moorman and Rust 1999) find a direct relationship between the influence of the MF within the organization and its effect on BP. Others (e.g. Verhoef and Leeflang 2009) find that the influence of the MF within the organization mediates the relationship between marketing roles, market orientation and BP and then respect among top management is associated with BP (Nath and Mahajan 2011; Verhoef and Leeflang 2009). A MF that can demonstrate its effect on BP can presumably create respect among top management and increase its influence within the organization. How the different types of MFs create results vary and therefore different types of MFs create respect among top management in different ways. Thus:

P3: There is variation in how different types of MFs create (a) respect among top management and (b) effect on BP. 
Martensen and Mouritsen's (2014) model can be extended and by including top management's respect (see Figure 1) it becomes possible to investigate how different types of MF influence BP and top management's respect. As these two effects are possibly related it is useful to apply a model that takes these two effects into account simultaneously. We assume that the same relationships exist between roles and top management's respect as between roles and BP.

\section{Figure 1 in about here}

Figure 1 shows that MF creates respect among top management and BP by focusing on traditional core marketing roles (little m) and/or market developing roles (Big M) (Morgan, Castle Graaf, and Vorhier 2009; Verhoef and Leeflang 2009). Big M and little m influence each other and this dynamic increases their individual effect. Recruitment, retention and development of competent staff (HRM marketing) ensure that market insight is collected and disseminated in the organization and forms the basis for the execution of both big M and little m (Hooley et al. 2005; Patterson et al. 1997). Martensen and Mouritsen (2014) tested and validated part of the model in Figure 1 (excluding top management's respect) based on an empirical study with almost 400 marketing managers. They study all the MFs as a whole and find that the organization of the roles and their link to BP can be confirmed and that the seven roles have very different effect on BP. Martensen and Mouritsen (2014) did not study how types of MFs influence BP and top management's respect simultaneously (see Figure 1).

\section{Method}

This study uses Martensen and Mouritsen's (2014) measurement scales for the seven marketing roles. Measurement scales for top managements respect are based on O'Sullivan and Abela (2007), Moorman and Rust (1999) and Kohli and Zaltman (1988). Scales for market results are based on Desphandé, Farley and Webster (1993), Homburg and Pflesser (2000), Koli and Jaworski (1990), Morman and Rust (1999), Ramaswani, Bhargava and Srivastava (2004) and Zhou et al. (2009). 
Financial results are based on Morman and Rust (1999), Verhoef and Leeflang (2009) and Zhou et al. (2009). Martensen and Mouritsen (2014) report high validity and reliability measures for all measurement scales. In total 46 questions formulated as statements from 1=strongly disagree to $7=$ strongly agree are used (see Appendix).

An online survey was carried out with Danish marketing managers. The respondents were contacted either by email or by phone. A total sample of 2,500 telephone numbers and 1,144 emails from the largest marketing interest organization in Denmark, and 500 e-mails to randomly selected companies were used for recruitment. A total of 550 useable interviews with marketing managers were carried out. 395 interviews were used in this survey. Response rates of $17 \%$ (telephone), 19\% (e-mails from interest organization) and 14\% (random e-mails) were achieved. Approximately $57 \%$ of the respondents were sales/marketing managers and approximately $34 \%$ were CEO's with main responsibility for managing the MF. The remaining respondents did not provide the information. $22 \%$ of the companies sold primarily to Business-to-Consumer markets, $53 \%$ primarily to Business-to-Business markets and the rest to public organizations. $53 \%$ of the respondents came from companies with less than 50 employees, and $16 \%$ came from companies with more than 250 employees.

\section{Results}

\section{Grouping marketing functions into types and estimating their effect}

MFs can be grouped into types by how they practice the seven marketing roles via cluster analysis. This makes MFs homogeneous in their efforts on the seven roles within the type but heterogeneous between types.

Two different types of cluster analysis are carried out to determine the most relevant number of types of MFs and afterwards describing them. First a K-means cluster analysis is carried out (cf. 
the SPSS procedure), where 3, 4 and 5 cluster solutions are analyzed (see also Jensen and Thorbjørn 2014; Malhotra et al. 2012). It is obvious from various frequencies and cross-tab analysis that the four cluster solution is the one giving most sense when describing each cluster according to various demographic and other background characteristics. The description of the final 4 clusters are described and elaborated on below based on these background characteristics. However, to further confirm that the 4 cluster solution is good and suitable, a Two-step cluster analysis is carried out. Besides confirming the 4 cluster solution, it also describes each cluster on the different background characteristics as in the K-means analysis. This leads to the following characteristics of the four types of MFs: (1) The broad-spectrum MF who to a large extent carries out activities within both little m and big M; (2) The hesitant MF who carries out limited activity in both little $\mathrm{m}$ and big M; (3) The market-creating MF who carries out less activities than the broadspectrum MF, but more activities than the traditional MF and with predominance of little $\mathrm{m}$ activities in combination with innovation and market intelligence; (4) The traditional MF who carries out fewer activities than the market-creating MF, but more than the hesitant MF and with a predominance of only little $\mathrm{m}$ activities.

The model in Figure 1 forms the basis for analyzing the types and their interaction with top management's respect and BP. The model is analyzed as a structural equations model for each of the four types of MFs using partial least squares (PLS) as estimation technique (Chin 1998; Fornell and Cha 1994). The seven marketing roles are specified as reflective (Jarvis et al. 2003) where direction of causality is from roles to items, reflecting a single, common underlying construct or theme. BP and top management's respect are specified as formative (Jarvis et al. 2003). Paths coefficients are shown in Table 1B-1E as well as Average Variance Extracted (AVE), composite reliability (CR), correlations and discriminant validity (Fornell-Larcker Criterion) which are all well above required standards. 
Table 1A summarizes the roles' total effects (the unstandardized values of the sum of the direct and indirect effects) on top management's respect, market- and financial results for each of the four types of MFs. Table 1A also shows the four types of MFs' average effort for each of the seven roles, top management's respect and BP, referred to as indexes. These indexes are calculated as a weighted mean of the answers to questions included under each of the latent variables to reflect how much effort the MF puts into each role. Loadings from the PLS analysis are used as weights. To ease interpretation of the indexes, the original 7-point scale is transformed to a 0-100 (low-high) index.

\section{Table 1A-1E in about here}

\section{Characteristics of the four types of marketing functions}

The types of MF have the following backgrounds:

1. The broad-spectrum $\mathbf{M F}$ has more marketing employees per employee than other type and it invests heavily in marketing. The MF is managed by a marketing executive/CMO who is recognized by top management and reports directly hereto. It invests in all seven roles, i.e. it implements both traditional marketing tasks (little $\mathrm{m}$ ) and participates in the development of the company through innovation and internal and external coordination (big M). On average, companies are large with a predominance of $\mathrm{BtC}$ activities compared to the three other types of functions.

2. The hesitant $\mathbf{M F}$ is in many ways opposite to the broad-spectrum MF. The companies are primarily within the $\mathrm{BtB}$ market and are either small or very large. It is to a lesser degree respected by top management despite the fact that it is often the CEO himself who manages the function. This indicates that marketing is not particularly important to the company and its performance. This is supported by the fact that there are few marketing employees, and it is the type of function that invests the least in marketing. 
3. The traditional $\mathbf{M F}$ focuses on marketing implementation and to some degree cross-functional coordination and HRM. The MF, managed typically by a marketing executive/CMO, is rarely represented on the Board and is less recognized by top management. Just like the broadspectrum MF it covers numerous medium and large companies and have many marketing employees.

4. The market-creating $\boldsymbol{M F}$ develops new markets and implements marketing activities according to the plans that the marketing strategy outlines. These activities are supported by market intelligence. The aim is to move the market and develop it. The MF is typically managed by the CEO and obtains high respect from top management. Both the company and the MF are small. Marketing investments are relatively high, with investments a little below the level of the broadspectrum and the traditional type of MF.

The above analysis confirms P1: MFs can be divided meaningfully into types according to their effort on seven generic marketing roles.

\section{Effort and effects in the four types of marketing functions}

Table 1A gives rise to a number of considerations. The four types of MFs create very different performances of BP (Index values). The broad-spectrum MF creates the highest BP. The traditional and the market-creating MF have more or less the same level that is lower than the broad-spectrum MF's BP. The hesitant MF has the lowest BP. A similar pattern happens for top management's respect where the market-creating MF achieves significantly better results than the traditional one. It is interesting to notice that the market-creating MF has a strong focus on innovation compared to the traditional MF's limited focus on innovation (index 61 vs 36), achieve identical market results (index 68 vs 69), but their financial performance differs significantly (index 67 vs 63).

Comparing the four types of MFs' level of effort shows that the broad-spectrum type puts a great deal of effort into all roles while the hesitant MF does not. The traditional and market-creating 
MFs are somewhere in between and put somewhat identical level of effort into measurement of effectiveness and cross-functional coordination but differ significantly on the other five roles.

This analysis confirms P2: There is variation in how MFs perform marketing roles that are carried out with different intensities across MFs.

When studying the levels of effort and total effects more specifically, Tables 1A-1E show that the broad-spectrum MF mobilizes marketing implementation which leads to influencing top management's respect. It has also a very strong focus on marketing strategy which has the highest total effect of all roles on both market results and financial performance. High effort is also devoted to market intelligence and coordination, but it is only the former which transforms into high total effects on top managements respect and BP.

The strategic focus is not very pronounced in the traditional MF and both strategy and implementation have high positive effects on top management's respect, but none or even high negative effects on BP. This may be a contributing factor to the lower level of financial performance relative to the broad-spectrum and the market-creating MF.

The market-creating MF invests relatively much in market intelligence which is important to top management and primarily used to support the strategy which leads to respect among top management and BP. Innovation also has high attention and has the highest positive effect on financial performance of all roles.

The hesitant MF generally has little focus on marketing. The effort on the seven roles has all index values of 19 or less and no role is more prominent than any other except measurement of effectiveness which has a significantly lower level (index10). Yet, the hesitant function achieves market- and financial results of 57 and 52 compared to the broad-spectrum function's index of 73 and 69. The differences are significant. However, BP is not as low as one might expect for the 
hesitant MF given its level of effort. This indicates that there are alternatives to MF in firms such as other functional areas that have suggestions to how customers and markets can be understood.

\section{Prioritizing marketing roles in the four types of marketing functions}

The results in Table 1A are graphically summarized in a priority map for each of the four types of MFs in Figure 2. The priority maps are formed by combining the indexes for each roles, i.e., how much effort the MF puts into each role, with the role's total effect on the response variables, i.e., the relative effect of a one point extra effort of each role on top management's respect and BP.

\section{Figure 2 in about here}

The three vertical lines indicate the average total effect respectively for market results, financial performance and top management's respect. The horizontal line is the average effort of the seven marketing roles.

The priority maps show that the four types of MF behave differently with significant positive and negative variation in how they create results. This confirms P3: There is variation in how different types of MFs create (a) respect among top management and (b) effects on BP. Moreover, each priority map shows large variation in how the individual role affects top management's respect and $\mathrm{BP}$ and whether the impact is positive or negative. This may challenge the MFs when prioritizing their investments.

To analyze how each MF can prioritize investments the roles are categorized according to how many positive/negative effects the roles have on the three response variables (top management respect, financial performance and market performance). This gives four possible outcomes. Investments in roles with: (1) three positive effects; (2) two positive effects; (3) one positive effect; (4) no positive effects or only negative effects. The results are summarized in Table 2. The argument for the categorization is that investing in roles with a positive effect on all three response variables generates better results than roles with two positive effects which creates better results 
than roles with only one positive effect. The last category, consisting of roles with no positive effects or directly negative effects, can also be essential to invest in as (large) negative effects can be a barrier to creating (high) results. The challenge here is to neutralize the negative effects, or even create positive effects, by understanding why the roles influence the response variables negatively, and with this knowledge develop new processes, methods, etc. that can create the necessary changes.

\section{Table 2 in about here}

The four outcomes in Table 2 indicate very different management tasks where particularly roles with very different (positive/negative) effects can provide managerial dilemmas.

In market-creating MFs particularly marketing strategy and development of market insight have positive effects while implementation provides negative effects. This MF faces certain dilemmas since some roles, e.g. innovation, are positively related to financial performance but it does not create respect from top management.

The broad-spectrum MF practices numerous roles with 2 or 3 large positive effects. In a sense this is where investment in marketing may seem unconstrained. Yet, there are dilemmas, as here is ambiguity about the role of innovation which fuels top management's respect while it links poorly with market results and has negative effect on financial results.

The traditional and hesitant MFs have only 1 role with 3 positive effects (respectively coordination and market intelligence) but they only create small effects. These MFs are ambiguous because they have several roles with just one positive effect. Also, even if little $\mathrm{m}$ activities tend not to lead to financial effects these roles have a relative high influence on top management's respect. This is a dilemma. Likewise, the market-creating MF puts a lot of effort into implementation and coordination but these investments tend not to create respect among top management and to produce a negative effect on financial performance. 
These results challenge Verhoef and Leeflang's (2009) results who recommend the same solutions for all MFs in the form of Innovativeness and Accountability. This study's results demonstrate that different types of MFs would benefit from performing different roles because of their different starting points. This confirms once more P2: There is variation in how MFs perform marketing roles that are carried out with different intensity across MFs and P3: There is variation in how different types of MFs create (a) respect among top management and (b) effects on BP.

\section{Discussion and conclusion}

This research adds to recent literature which has discussed the influence of the MF from a pessimistic view. In contrast, this research shows a positive agenda for the development of the MF and its raison d'etre in the company. This is a complex agenda because not all MFs are expected to behave in the same way. Firstly new efforts and investments depend on previous levels of investment and effort. This means that the marginal effect of investments in a particular marketing role depends on the type of MF in question. As the study shows the four MFs require different investments to increase their performance. Secondly, this is also a complex agenda because particular investments may load highly on some performance variables and lowly and even negatively on others. The most interesting point is that many investments are strongly associated with top management respect but not with financial and market performance. Top managers may not really know how to evaluate the efforts of MFs. This is problematical because it may be that to gain visibility MFs will have to do things that will not help the firm's development in the market. Verhoef and Leeflang (2009) assume that the influence of the MF only goes through top management's respect, other functional areas recognition and increased decision-making power. If this is true, then it is clear that marketing may not always help the business: influence and respect may run counter to business effects. 
MFs are different. While this may not be surprising in principle, the study shows that this difference is highly important and influential. From the point of view of development, it is clear that different starting points will benefit from very different strategies for developing the importance of MFs. There is no single path to a profitable and rewarding future. The study shows in quite some detail which investments of effort increase performance under different conditions and thus offer a decision oriented approach to developing MFs. Rather than assuming that all, or most, marketing roles are worth promoting, the study shows a heterogeneity that is both realistic and also bewildering. There is no simple and single path to profitability and rewards. Managers are required to understand the properties of the specific MF in detail and then to embark on investments each of which may benefit some performance targets but not necessarily all.

Decision making about the future development of MFs is therefore complex. This point may not be surprising since a long string of marketing research has seen this as a problem and seeks to find underlying factors that might explain a lot of variables. The sensible aim has been to simplify decision making. However, due to the heterogeneity demonstrated by this study, this may not be an advisable strategy. The average effect explains too little. The fact that it is possible to characterize 4 different MFs illustrates that attention to difference is an interesting managerial strategy. This is not an easy strategy, but it is one that requires of managers that they do engage with MF strategically. They will need to be concerned with precise effects rather than general ones and they will have to develop their own ways of dealing with the dilemmas and paradoxes that will ensue since only few investments will align preferred effects both in relation to business performance and respect from top management. Findings show that the roles effect and priority depends on the type of MF, why the MF's next move depends on what type it is. This creates knowledge about the strategic priorities within each type of MF and helps to tackle two key issues previously neglected in the literature. 
To conclude, firstly, the study shows that all roles are not equally important to practice. There is significant variation about what MFs do and how this is related to $\mathrm{BP}$ and respect from top management. As a consequence there is no simple way towards performance. There are dilemmas.

Secondly, the study shows roles are not equally important to all MFs, but depend on the MF's unique starting point. There seems to be four types of MFs based on how they perform marketing roles. This variation indicates that from the perspective of decision making, MFs face different starting points for developing BP and respect among top management.

The study shows benefits from investing not only in less developed marketing functions; it also pays off to develop high performing MFs. While others suggest that lowly performing marketing functions can and should develop, it is less clear what they say about highly performing MFs. Such research seems to be concerned more with identifying the general roles and capabilities that may lift weak MFs into strong ones (Kumar 2008; Moorman and Rust 1999; O'Sullivan and Abela 2007; Stewart 2009; Sheth and Sisodia 2005; Verhoef and Leeflang 2009). The present study suggests that all MFs can develop. It also suggests that not everybody can develop by the same investments. This is a conclusion that recreates role for managers to make the trade-offs between the different roles and their different effects under different conditions.

\section{Limitations and future research}

The classification of MFs into types according to their effort on seven marketing roles is relevant and useful from a theoretical as well as a managerial perspective. However, this study is limited to only Danish companies and their MFs and their numbers within each type is also limited. Hence, there is obviously a need for generalization, e.g. by using more data and from other countries as well. The study also uses self-reported data of BP and not actual performance data. Previous research shows that self-reported data generates stronger relationships (Cano et al. 2004). Moreover, top managements' respect was reported by the CMOs and not the CEOs themselves. 
Multiple respondents' per company, i.e. both the CEOs and the CMOs evaluations, may have rendered more reliable results.

It may also be interesting to study how different types of MFs interact with other functional areas in the company. Will the broad-spectrum MF, for example, to a greater extent interact with the finance function compared to the traditional MF? Will the market-creating MF to a greater extent interact with $\mathrm{R} \& \mathrm{D}$ than the traditional MF?

\section{References}

Bharadwaj, S.G., Varadarajan, P.A. \& Fahy, J. (1993). Sustainable Competitive Advantage in Service Industries: A Conceptual Model and Research Proposition. Journal of Marketing, 57, 8399

Bolton, R.N. (2006). The Implications of 'Big M' Marketing for Modeling Service and Relationships. Marketing Science, 25, 584-586

Brown, S.W., F.E. Webster Jr., J-B.E.M. Steenkamp, W.L. Wilkie, J.N. Sheth, \& R.S. Sisodia, (2005), “Marketing Renaissance: Opportunities and Imperatives for Improving Marketing Thought, Practice, and Infrastructure," Journal of Marketing, 69 (October), 1-25.

Cano, C.R., F.A. Carrillat, \& F.Jaramillo(2004), “A Meta-Analysis of the Relationship Between Market Orientation and Business Performance: Evidence from Five Continents," International Journal of Research in Marketing, 21 (2), 179-200.

Chin, W.W. (1998). Issues and Opinion on Structural Equation Modeling. MIS Quarterly, 22, vii-xvi.

Day, G.S. (1994). “The Capabilities of Market-Driven Organizations,” Journal of Marketing, 58 (October), 37-52.

Day, G.S. (2011). Closing the Marketing Capabilities Gap, Journal of Marketing, 75 (183, July), 183-195 Deshpandé, R, J.U. Farley, \& F.E, Webster,Jr. (1993), "Corporate Culture. Customer Orientation, and Innovativeness in Japane.se Firms; A Quadrad Analysis." Journal of 
Marketing. 52 (January). 23-36.

Fornell, C. \& Cha, J. (1994). Partial least square. In R. P. Bagozzi (Ed.), Advanced methods of marketing research (52-78). Cambridge, Massachusetts: Blackwell

Gordon, J., \& Perrey, J. (2015). The dawn of marketing's new golden age. McKinsey Quaterly. Retrieved from

http://www.mckinsey.com/insights/marketing_sales/the_dawn_of_marketings_new_golden_age

Grönroos, C. (2006). On defining marketing: finding a new roadmap for marketing, Marketing theory, 6(4), 395-417.

Han, J.K., Kim, N. \& Srivastava, R K. (1998). MO and Organizational Performance: Is Innovation a Missing Link?. Journal of Marketing, 62, 30-45.

Homburg, C. \& Pflesser, C. (2000). A multiple-layer model of market-oriented organizational culture: measurement issues and performance outcomes. Journal of Marketing Research, 37, 449462

Homburg, C., J.P. Workman, \& H. Krohmer (1999), "Marketing's Influence Within the Firm,” Journal of Marketing, 63 (April), 1-17.

Homburg, C., Vomberg, A., Enke, M., \& Grimm, P.H. (2014). The loss of the marketing department's influence: is it really happening? And why worry? Journal of the Academy of Marketing Science, 43(1), 1-13.

Hooley, G.J., G.E. Greenley, J.W. Cadogan, \& J. Fahy (2005). “The performance impact of marketing resources", Journal of Business Research, 58, 18-27

Hunt, S.D. \& Morgan, R.M. (1995). The comparative advantage theory of competition. Journal of Marketing, 59, 1-15

Jarvis, C,.B, MaCkenzie \& Podsakoff, P.M. (2003). A critical review of construct indicators and measurement model misspecification in marketing and consumer research. Journal of Consumer Research, 30, 199-218 
Jensen, Jan Møller \& Knudsen, Thorbjørn (2014). Analyse af spørgeskemadata med SPSS: Teori, anvendelse og praksis, 3. udgave, Odense: Syddansk Universitetsforlag

Kohli, A.K. \& Jaworski, B.J. (1990). Market Orientation: The Construct, Research Propositions, and Managerial Implications. Journal of Marketing, 54, 1-18

Kohli, A.K. \& G.Zaltman (1988), "Measuring Multiple Buying Influences," industrial Marketing Management. 17 (August), 197-205,

Kumar, N. (2008). ’The CEO’s Marketing Manifesto”, Marketing Management, December: 24-29.

Lehmann, D.R. (1997). "Some thoughts on the futures of marketing”, In D.R. Lehmann \& K.E. Joez (eds.). Reflections on the futures of marketing (Chapt 6, pp. 121-135), Cambridge, MA:Marketing Science Institute.

Malhotra, Naresh K., Birks, David F. \& Wills, Peter (2012). Marketing Research: An Applied Approach, Fourth Edition. Pearson Education.

Martensen, A.\& J. Mouritsen (2014). "Prioritizing Investments in Marketing Activities to Improve Business Performance”, Total Quality Management \& Business Excellence, 25(5-6), 582-601.

Moorman, C., \& Rust, R. (1999). The role of marketing. Journal of Marketing, 63(SI),180-197.

Moorman, C., \& Slotegraaf, R. J. (1999). The contingency value of complementary capabilities in product development. Journal of Marketing Research, 36(2), 239-257.

Morgan, N.A., R.J. Slotegraaf, \& D.W. Vorhies (2009). "Linking marketing capabilities with profit growth", International Journal of Research in Marketing, 26,284-293.

Morgan, N.A., Vorhies, D.W. \& Mason, C.H. (2009). Market Orientation, Marketing Capabilities, and Firm Performance. Strategic Management Journal, 30, 909-920

MSI. (1996). Guide to MSI Research Programs and Procedures. Marketing Science Institute Research Priorities.

Nath, P., \& Mahajan, V. (2008). Chief Marketing Officers: A Study of Their Presence in Firms' Top Management Teams. Journal of Marketing, 72(January), 65-81. 
Nath, P., \& Mahajan, V. (2011). Marketing in the C-Suite: A Study of Chief Marketing Officer Power in Firms’ Top Management Teams. Journal of Marketing, 75(January), 60-77.

O’Sullivan, D. \& A.V. Abela (2007), “Marketing Performance Measurement Ability and Firm Performance," Journal of Marketing, 71 (April), 79-83.

Patterson MG, West MA, Lawthom R, \& Nickell S. (1997). Impact of people management practices on business performance. London: Institute for Personnel and Development, Issues in People Management No 22.

Ramaswami, S.N., M.Bhargava, \& R. Srivastava (2004). "Market-based Assets and Capabilities, Business Processes, and Financial Performance (04-102)", MSI Reports, Working paper series, Issue one, No. 04-001,47-73.

Rogers, D., \& Sexton, D. (2012). Marketing ROI in the Era of Big Data: The 2012 BRITE/NYAMA Marketing in Transition Study. New York, NY

Schultz D.E. (2005). “MR Deserves Blame for Marketing's Decline,” Marketing News, (February $15), 7$.

Sheth, J.N. \& R.S. Sisodia (2005), “A Dangerous Divergence: Marketing and Society,” Journal of Public Policy \& Marketing, 24 (Spring), 160-62.

Srivastava, R. K., Shervani, T. A. \& Fahey, L. (1998). Market-Based Assets and Shareholder Value: A Framework for Analysis. Journal of Marketing, 62, 2-18

Srivastava, R. K., Fahey, L. \& Christensen, H. K. (2001). The resource-based view and marketing: The role of market-based assets in gaining competitive advantage. Journal of Management, 27, 777-802 Srivastava, R.K., T.A. Shervani, \& L.Fahey (1999). "Marketing, Business Processes, and Shareholder Value: An Organizationally Embedded View of Marketing Activities and the Discipline of Marketing”, Journal of Marketing, 63(October),168-179. 
Stewart, D.W. (2009). Marketing accountability: Linking marketing actions to financial results, Journal of Business Research, 62, 636-643.

Verhoef, P.V. \& Leeflang, P.S.H. (2009). Understanding the Marketing Department's Influence Within the Firm, Journal of Marketing, 73(March), 14-37

Vorhies, D.W. \& Morgan, N.A. (2005). Benchmarking Marketing Capabilities for Sustainable Competitive Advantage, Journal of Marketing, 69 (January 2005), 80-94

Webster, F.E. (2005), "Back to the Future: Integrating Marketing as Tactics, Strategy, and Organizational Culture," in "Marketing Renaissance: Opportunities and Imperatives for Improving Marketing Thought, Practice, and Infrastructure,” Journal of Marketing, 69 (October), 1-25.

Webster, F.E., A.J. Malter, \& S. Ganesan (2005). The Decline and Dispersion of Marketing Competence, MIT Sloan Management Review, 46(4), 35-43.

Zhou, K.Z., Brown, J.R. \& Dev, C.S. (2009). MO, Competitive Advantage, and Performance: A DemandBased Perspective. Journal of Business Research, 2, 1063-1072 
Figure 1.

Conceptual model for the structure of the marketing roles and their link to top management's respect and business performance

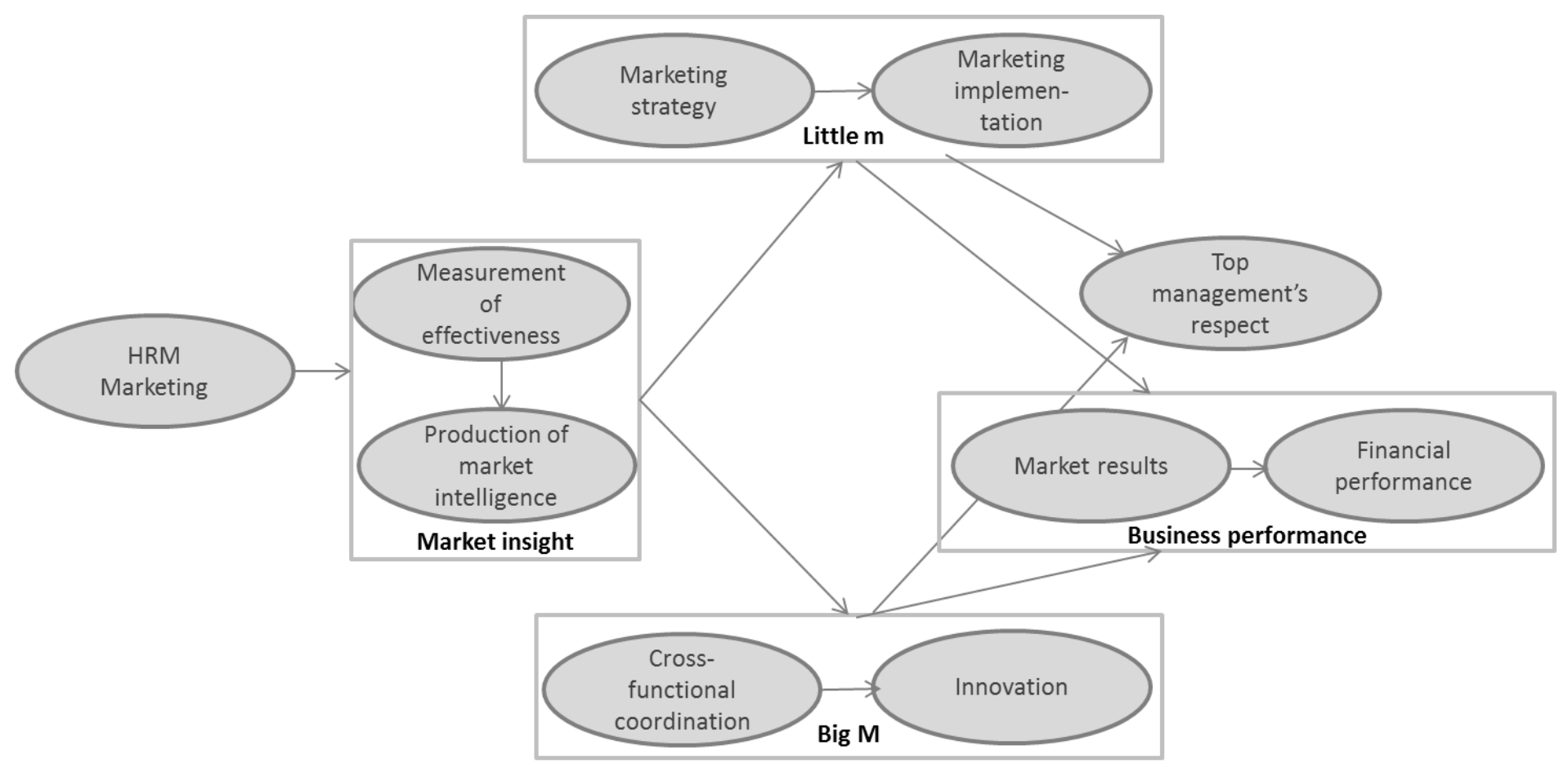


Figure 2

Priority maps for the four types of marketing functions

\section{A. Broad-spectrum}

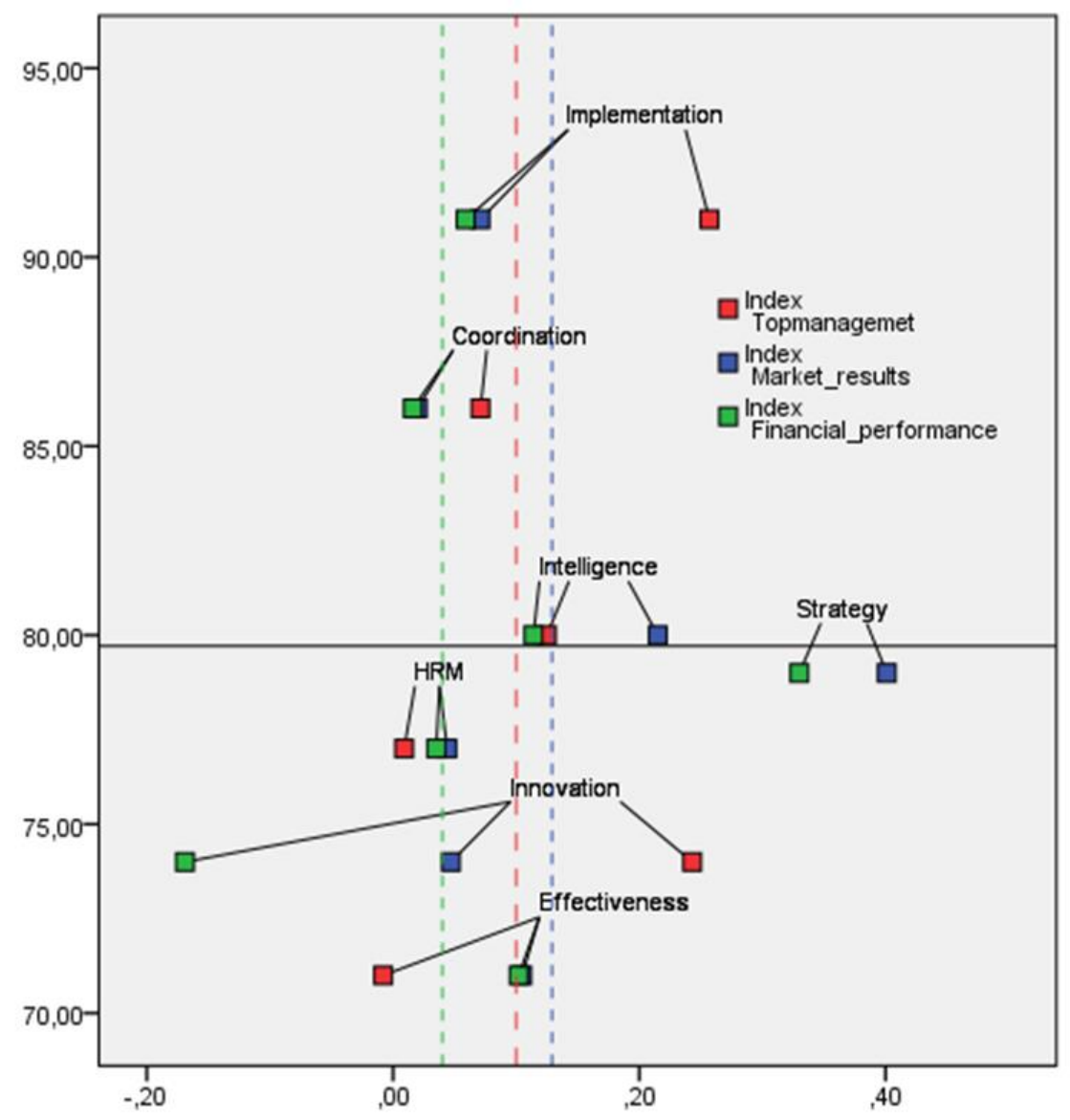




\section{B. Market-creating}

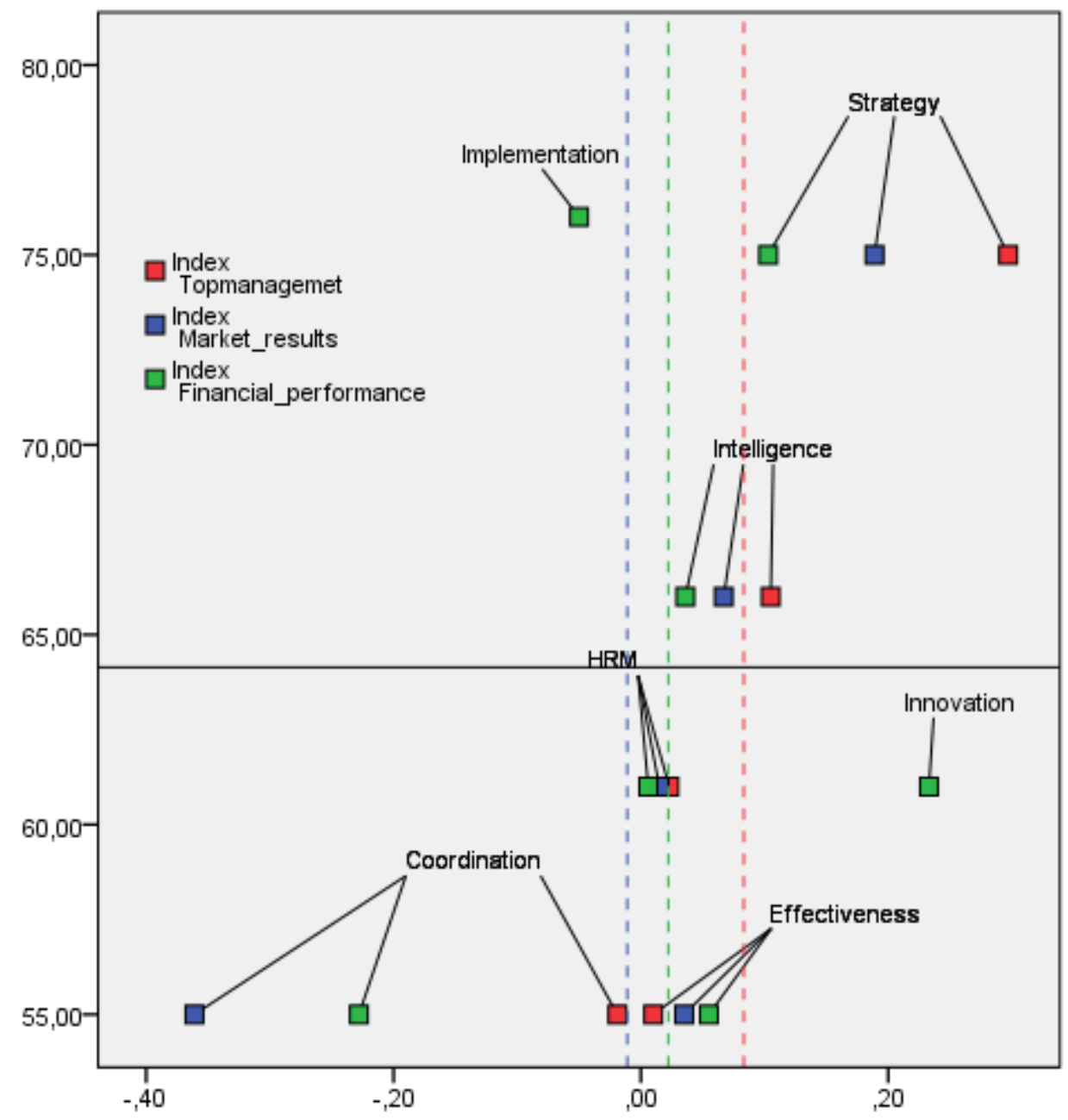




\section{Traditional}

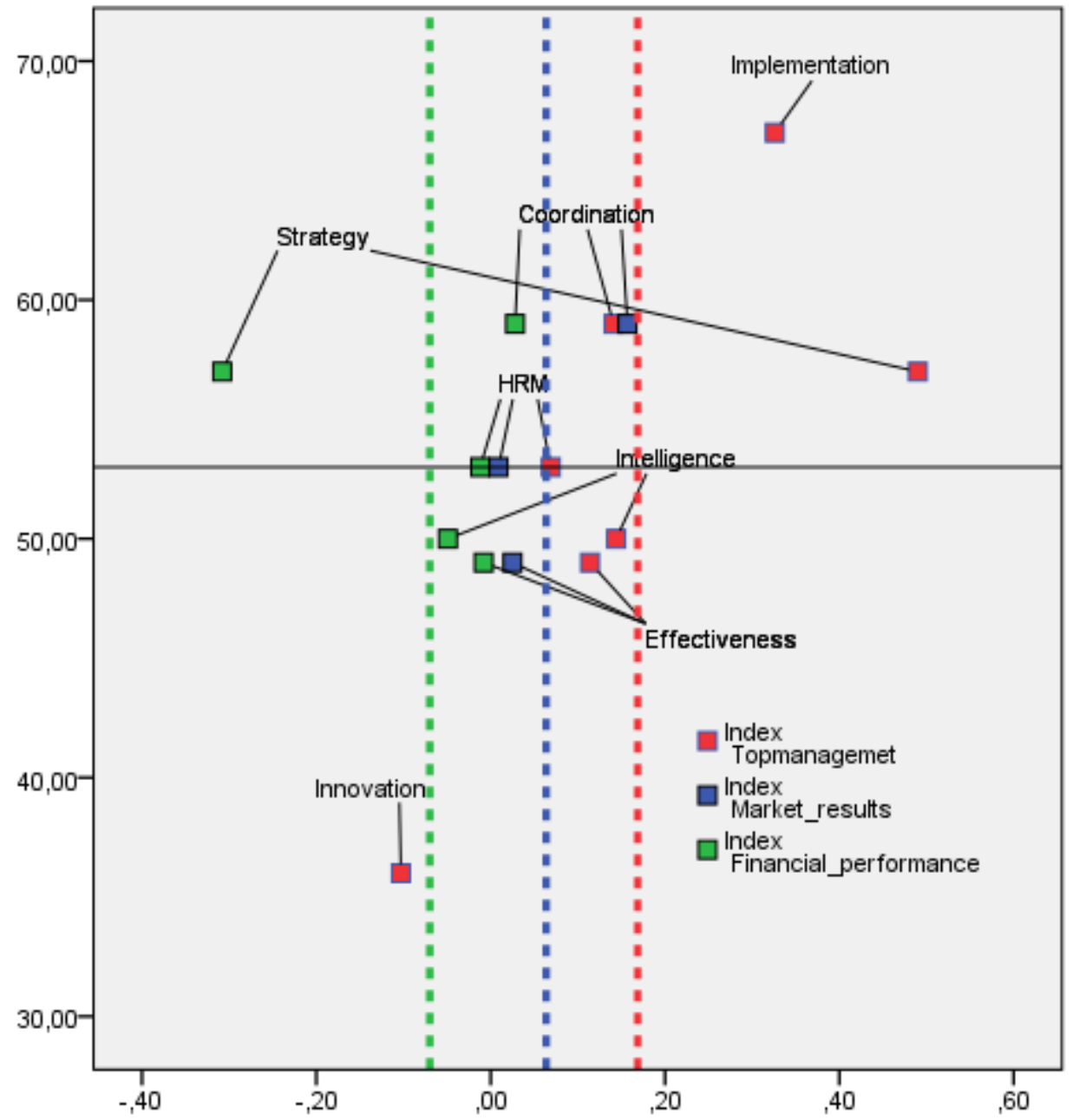


D. Hesistant

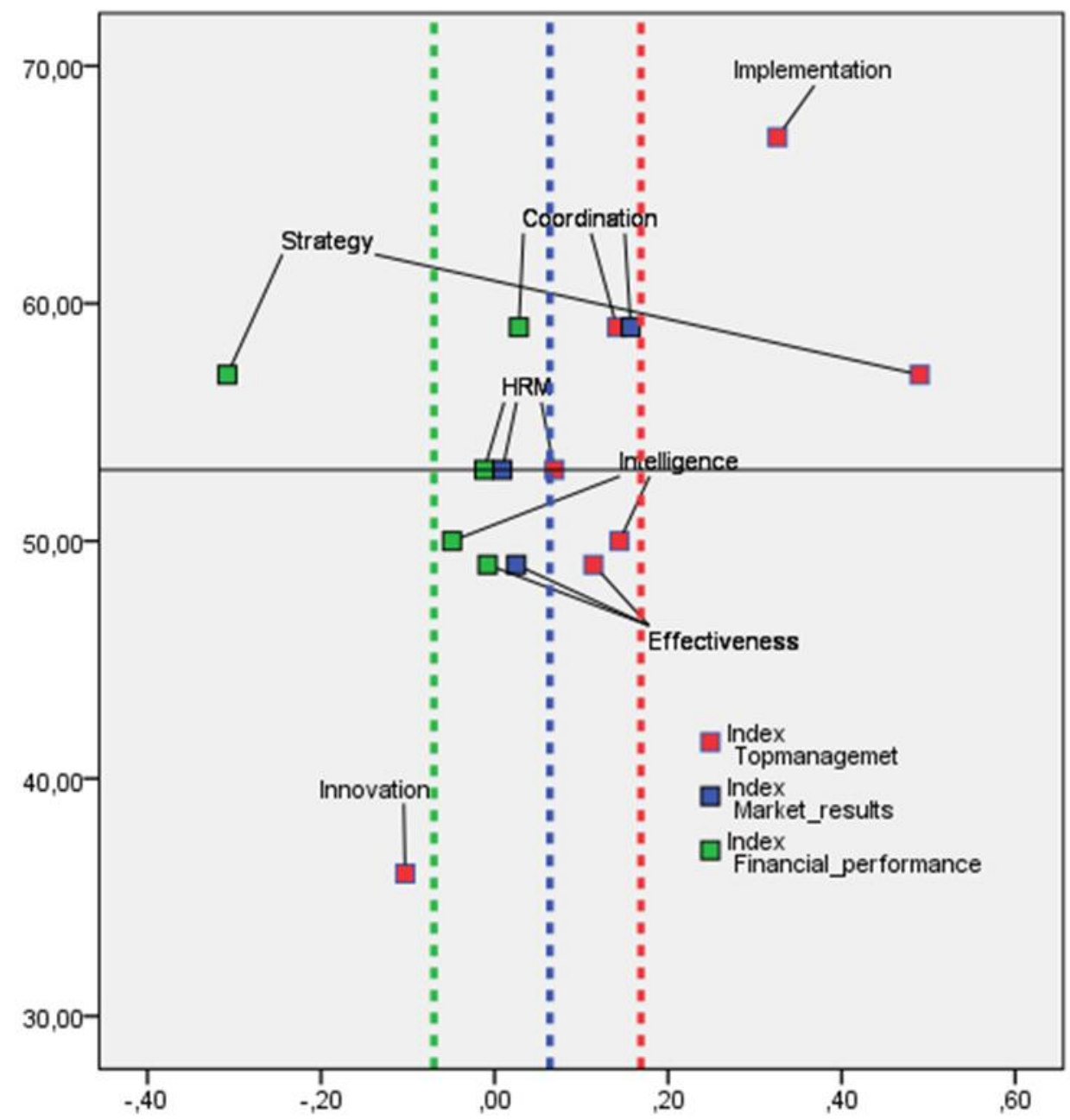


Table 1A. Indexes and total effects for each of the four types of marketing functions ${ }^{1}$

\begin{tabular}{|c|c|c|c|c|c|c|c|c|c|c|c|c|c|c|c|c|c|}
\hline \multirow[b]{2}{*}{ Roles } & \multirow{2}{*}{$\begin{array}{l}\begin{array}{l}\text { Total } \\
\text { sample }\end{array} \\
(\mathbf{N}=395)\end{array}$} & \multicolumn{4}{|c|}{$\begin{array}{l}\text { Hesitant } \\
(\mathrm{N}=55 ; 14 \%) \\
\\
\text { Total effect }^{2}\end{array}$} & \multicolumn{4}{|c|}{$\begin{array}{l}\text { Traditional } \\
(\mathrm{N}=115 ; 29 \%) \\
\text { Total effect }\end{array}$} & \multicolumn{4}{|c|}{$\begin{array}{l}\text { Market-creating } \\
(\mathrm{N}=109 ; 28 \%) \\
\text { Total effect }\end{array}$} & \multicolumn{4}{|c|}{$\begin{array}{l}\text { Broad-spectrum } \\
(\mathrm{N}=116 ; 29 \%) \\
\text { Total effect }\end{array}$} \\
\hline & & Index & $\begin{array}{c}\text { Top- } \\
\text { manage } \\
\text { ment } \\
\text { respect }\end{array}$ & $\begin{array}{l}\text { Mar- } \\
\text { ket } \\
\text { results- }\end{array}$ & $\begin{array}{l}\text { Finan- } \\
\text { cial } \\
\text { results }\end{array}$ & Index & $\begin{array}{c}\text { Top- } \\
\text { manage } \\
\text { ment } \\
\text { respect }\end{array}$ & $\begin{array}{l}\text { Mar- } \\
\text { ket } \\
\text { results- }\end{array}$ & $\begin{array}{l}\text { Finan- } \\
\text { cial } \\
\text { results }\end{array}$ & Index & $\begin{array}{c}\text { Top- } \\
\text { manage } \\
\text { ment } \\
\text { respect }\end{array}$ & $\begin{array}{l}\text { Mar- } \\
\text { ket } \\
\text { results- }\end{array}$ & $\begin{array}{c}\text { Finan- } \\
\text { cial } \\
\text { - results }\end{array}$ & Index & $\begin{array}{c}\text { Top- } \\
\text { manage } \\
\text { ment } \\
\text { respect }\end{array}$ & $\begin{array}{l}\text { Mar- } \\
\text { ket } \\
\text { results- }\end{array}$ & $\begin{array}{c}\text { Finan- } \\
\text { cial } \\
\text { results }\end{array}$ \\
\hline Role 1: Marketing implementation & 64 & 17 & 1.270 & - & - & 67 & .326 & - & - & 76 & - & - & -.050 & 91 & .257 & .071 & .059 \\
\hline Role 2: Marketing strategy & 60 & 15 & - & - & .135 & 57 & .490 & - & -.308 & 75 & .297 & .189 & .103 & 79 & - & .401 & .330 \\
\hline Role 3: Innovation & 55 & 17 & -.405 & .320 & .285 & 36 & -.103 & - & - & 61 & - & - & .233 & 74 & .243 & .047 & -.169 \\
\hline $\begin{array}{l}\text { Role 4: Production of market } \\
\text { intelligence }\end{array}$ & 58 & 19 & .319 & .218 & .103 & 50 & .144 & - & -.049 & 66 & .105 & .067 & .036 & 80 & .125 & .215 & .114 \\
\hline Role 5: Measurement of effectiveness & 51 & 10 & .949 & .121 & -.089 & 49 & .114 & .025 & -.008 & 55 & .055 & .035 & .010 & 71 & -.008 & .105 & .102 \\
\hline Role 6: Cross-functional coordination & 56 & 13 & .918 & - & -.448 & 59 & .141 & .157 & .028 & 54 & -.019 & -.361 & -.228 & 86 & .071 & .020 & .016 \\
\hline Role 7: HRM Marketing & 58 & 16 & .314 & .040 & .314 & 53 & .069 & .009 & -.012 & 61 & .023 & .015 & .006 & 77 & .009 & .044 & .035 \\
\hline \multicolumn{18}{|l|}{ Respons variables } \\
\hline Top management's respect & 65 & 39 & $\mathrm{R}^{2}=.40$ & & & 63 & $\mathrm{R}^{2}=.25$ & & & 71 & $\mathrm{R}^{2}=.12$ & & & 82 & $\mathrm{R}^{2}=.12$ & & \\
\hline Market resultats & 72 & 57 & & & .891 & 69 & & & .658 & 68 & & & .634 & 73 & & & .822 \\
\hline Financial performance & 64 & 52 & $\mathrm{R}^{2}=.76$ & & & 63 & $\mathrm{R}^{2}=.52$ & & & 67 & $\mathrm{R}^{2}=.55$ & & & 69 & $\mathrm{R}^{2}=.64$ & & \\
\hline
\end{tabular}

\footnotetext{
${ }^{1}$ All 46 questions are transformed from the original 7-point scale to a 0-100 (low-high) scale

${ }^{2}$ Unstandardized
} 
Table 1B. Results of PLS-analyses for the Hesistant MF:

\section{Path coefficients, Average Variance Extrated (AVE), Composite reliablity (CR) and}

\section{Discriminant validity (Fornell-Larcker Criterion) ${ }^{3}$}

\begin{tabular}{|c|c|c|c|c|c|c|c|c|c|c|c|}
\hline & Coordination & Effectiveness & \begin{tabular}{|l}
$\begin{array}{l}\text { Financial } \\
\text { Performance }\end{array}$ \\
\end{tabular} & $\begin{array}{l}\text { Implemen } \\
\text { tation }\end{array}$ & Innovation & Intelligence & \begin{tabular}{|l|} 
Market \\
Performance \\
\end{tabular} & Strategy & \begin{tabular}{|l|} 
Topmanage \\
ment's \\
respect \\
\end{tabular} & AVE & CR \\
\hline Coordination & & & -0.243 & 0.507 & & & & 0.469 & & 0.59 & 0.81 \\
\hline Effectiveness & 0.383 & & & 0.317 & & 0.499 & & & & 0.60 & 0.81 \\
\hline HRM & & 0.406 & & & & & & & & 0.65 & 0.85 \\
\hline Implementation & & & & & & & & & 0.636 & 0.68 & 0.89 \\
\hline Innovation & & & & -0.318 & & & 0.220 & & & 0.61 & 0.75 \\
\hline Intelligence & 0.379 & & & 0.193 & 0.581 & & & 0.397 & & 0.56 & 0.79 \\
\hline Market Performance & & & 0.859 & & & & & & & - & - \\
\hline Strategy & & & 0.274 & & & & & & & 0.54 & 0.78 \\
\hline
\end{tabular}

\begin{tabular}{|c|c|c|c|c|c|c|c|}
\hline & Coordination & Effectiveness & HRM & Implementation & Innovation & Intelligence & Strategy \\
\hline Coordination & 0.768 & & & & & & \\
\hline Effectiveness & 0.572 & 0.775 & & & & & \\
\hline HRM & 0.427 & 0.406 & 0.804 & & & & \\
\hline Implementation & 0.625 & 0.542 & 0.651 & 0.822 & & & \\
\hline Innovation & 0.541 & 0.505 & 0.134 & 0.227 & 0.781 & & \\
\hline Intelligence & 0.570 & 0.499 & 0.347 & 0.455 & 0.581 & 0.748 & \\
\hline Strategy & 0.696 & 0.577 & 0.297 & 0.489 & 0.523 & 0.665 & .738 \\
\hline
\end{tabular}

\footnotetext{
${ }^{3}$ Diagonal entries are square root of the average variance extracted (AVE). Off-diagonal entries are the correlations between the latent variables.
} 
Table 1C. Results of PLS-analyses for the Broad-spectrum MF:

Path coefficients, Average Variance Extrated (AVE), Composite reliablity (CR) and

Discriminant validity (Fornell-Larcker Criterion)

\begin{tabular}{|c|c|c|c|c|c|c|c|c|c|c|c|}
\hline & Coordination & Effectiveness & $\begin{array}{l}\text { Financial } \\
\text { Performance }\end{array}$ & $\begin{array}{l}\text { Implemen } \\
\text { tation }\end{array}$ & Innovation & Intelligence & \begin{tabular}{|l|} 
Market \\
Performance \\
\end{tabular} & Strategy & $\begin{array}{l}\text { Topmanage } \\
\text { ment's } \\
\text { respect } \\
\end{array}$ & AVE & CR \\
\hline Coordination & & & & 0.441 & & & & & & 0.43 & 0.66 \\
\hline Effectiveness & & & & & -0.211 & 0.369 & & 0.200 & & 0.62 & 0.83 \\
\hline HRM & & 0.188 & & & & 0.155 & & & & 0.58 & 0.80 \\
\hline Implementation & & & & & & & 0.146 & & 0.209 & 0.58 & 0.81 \\
\hline Innovation & & & -0.192 & -0.174 & & & & 0.148 & 0.284 & 0.56 & 0.70 \\
\hline Intelligence & 0.262 & & & 0.271 & 0.258 & & & 0.443 & & 0.53 & 0.77 \\
\hline Market Performance & & & 0.787 & & & & & & & & \\
\hline Strategy & & & & & & & 0.156 & & & 0.59 & 0.80 \\
\hline
\end{tabular}

\begin{tabular}{|c|c|c|c|c|c|c|c|}
\hline & Coordination & Effectiveness & HRM & Implementation & Innovation & Intelligence & Strategy \\
\hline Coordination & 0.659 & & & & & & \\
\hline Effectiveness & 0.117 & 0.782 & & & & & \\
\hline HRM & 0.211 & 0.188 & 0.759 & & & & \\
\hline Implementation & 0.491 & 0.217 & 0.095 & 0.762 & & & \\
\hline Innovation & 0.123 & -0.108 & -0.009 & -0.072 & 0.747 & & \\
\hline Intelligence & 0.262 & 0.398 & 0.224 & 0.357 & 0.175 & 0.727 & \\
\hline Strategy & 0.071 & 0.360 & 0.268 & 0.079 & 0.204 & 0.548 & .770 \\
\hline
\end{tabular}


Table 1D. Results of PLS-analyses for the Traditional MF:

Path coefficients, Average Variance Extrated (AVE), Composite reliablity (CR) and

Discriminant validity (Fornell-Larcker Criterion)

\begin{tabular}{|c|c|c|c|c|c|c|c|c|c|c|c|}
\hline & Coordination & Effectiveness & $\begin{array}{l}\text { Financial } \\
\text { Performance }\end{array}$ & $\begin{array}{l}\text { Implemen } \\
\text { tation }\end{array}$ & Innovation & Intelligence & $\begin{array}{l}\text { Market } \\
\text { Performance }\end{array}$ & Strategy & $\begin{array}{l}\text { Topmanage } \\
\text { ment's } \\
\text { respect } \\
\end{array}$ & AVE & CR \\
\hline Coordination & & & & & -0.175 & & 0.218 & 0.280 & & 0.56 & 0.71 \\
\hline Effectiveness & 0.242 & & & 0.126 & & 0.225 & & & & 0.63 & 0.83 \\
\hline HRM & & 0.415 & & & & 0.250 & & & & 0.77 & 0.91 \\
\hline Implementation & & & & & & & & & 0.282 & 0.61 & 0.83 \\
\hline Innovation & & & & -0.374 & & & & & & 0.57 & 0.72 \\
\hline Intelligence & & & & 0.182 & -0.161 & & & 0.223 & & 0.58 & 0.72 \\
\hline Market Performance & & & 0.718 & & & & & & & - & t. \\
\hline Strategy & & & -0.177 & 0.317 & & & & & 0.301 & 0.63 & 0.77 \\
\hline
\end{tabular}

\begin{tabular}{|c|c|c|c|c|c|c|c|}
\hline & Coordination & Effectiveness & HRM & Implementation & Innovation & Intelligence & Strategy \\
\hline Coordination & 0.747 & & & & & & \\
\hline Effectiveness & 0.242 & 0.791 & & & & & \\
\hline HRM & 0.244 & 0.415 & 0.876 & & & & \\
\hline Implementation & 0.289 & 0.286 & 0.362 & 0.783 & & & \\
\hline Innovation & -0.197 & -0.139 & -0.094 & -0.477 & 0.754 & & \\
\hline Intelligence & 0.133 & 0.329 & 0.344 & 0.375 & -0.185 & 0.760 & \\
\hline Strategy & 0.310 & 0.153 & 0.230 & 0.445 & -0.163 & 0.260 & .796 \\
\hline
\end{tabular}


Table 1E. Results of PLS-analyses for the Market-creating MF:

Path coefficients, Average Variance Extrated (AVE), Composite reliablity (CR) and

Discriminant validity (Fornell-Larcker Criterion)

\begin{tabular}{|c|c|c|c|c|c|c|c|c|c|c|c|}
\hline & Coordination & Effectiveness & $\begin{array}{l}\text { Financial } \\
\text { Performance }\end{array}$ & $\begin{array}{l}\text { Implemen } \\
\text { tation }\end{array}$ & Innovation & Intelligence & $\begin{array}{l}\text { Market } \\
\text { Performance }\end{array}$ & Strategy & $\begin{array}{l}\text { Topmanage } \\
\text { ment's } \\
\text { respect } \\
\end{array}$ & AVE & CR \\
\hline Coordination & & & & & & & -0.266 & -0.139 & & 0.52 & 0.76 \\
\hline Effectiveness & & & & 0.243 & & 0.240 & & 0.221 & & 0.52 & 0.75 \\
\hline HRM & & 0.187 & & & & 0.190 & & & & 0.70 & 0.88 \\
\hline Implementation & & & 0.074 & & & & & & & 0.55 & 0.78 \\
\hline Innovation & & & 0.143 & -0.228 & & & & & & 0.58 & 0.72 \\
\hline Intelligence & & & & & & & & 0.269 & & 0.52 & 0.77 \\
\hline Market Performance & & & 0.718 & & & & & & & - & - \\
\hline Strategy & & & & 0.338 & & & 0.195 & & 0.340 & 0.59 & 0.74 \\
\hline
\end{tabular}

\begin{tabular}{|c|c|c|c|c|c|c|c|}
\hline & Coordination & Effectiveness & HRM & Implementation & Innovation & Intelligence & Strategy \\
\hline Coordination & 0.724 & & & & & & \\
\hline Effectiveness & -0.016 & 0.718 & & & & & \\
\hline HRM & -0.021 & 0.187 & 0.839 & & & & \\
\hline Implementation & 0.007 & 0.326 & 0.356 & 0.744 & & & \\
\hline Innovation & -0.158 & 0.076 & -0.015 & -0.193 & 0.763 & & \\
\hline Intelligence & -0.126 & 0.275 & 0.235 & 0.261 & -0.026 & 0.722 & \\
\hline Strategy & -0.176 & 0.297 & 0.412 & 0.400 & 0.047 & 0.347 & .769 \\
\hline
\end{tabular}


Table 2. Prioritizing the roles in the four types of marketing functions

\begin{tabular}{|c|c|c|c|c|}
\hline Level & Broad-spectrum & Traditional & Market-creating & Hesitant \\
\hline $\begin{array}{l}\text { Investments with } 3 \\
\text { positive effects }\end{array}$ & $\begin{array}{l}\text { Implementation (91) } \\
\text { Coordination (86) } \\
\text { Market insight (80) } \\
\text { HRM (77) }\end{array}$ & Coordination (59) & $\begin{array}{l}\text { Strategy (75) } \\
\text { Market insight (65) } \\
\text { HRM (61) } \\
\text { Effectiveness (55) }\end{array}$ & Market insight (19) \\
\hline $\begin{array}{l}\text { Investments with } 2 \\
\text { positive effects }\end{array}$ & $\begin{array}{l}\text { Strategy (79) } \\
\text { Innovation (74) } \\
\text { Effectiveness (71) }\end{array}$ & $\begin{array}{l}\text { HRM (53) } \\
\text { Effectiveness (49) }\end{array}$ & & $\begin{array}{l}\text { Innovation (17) } \\
\text { HRM (16) } \\
\text { Effectiveness (10) }\end{array}$ \\
\hline $\begin{array}{l}\text { Investments with } 1 \\
\text { positive effects }\end{array}$ & & $\begin{array}{l}\text { Implementation (67) } \\
\text { Strategy (57) } \\
\text { Market insight (50) }\end{array}$ & Innovation (61) & $\begin{array}{l}\text { Implementation (17) } \\
\text { Strategy (15) } \\
\text { Coordination (13) }\end{array}$ \\
\hline $\begin{array}{l}\text { Investments with } 0 \\
\text { or negative effects }\end{array}$ & & Innovation (36) & $\begin{array}{l}\text { Implementation (76) } \\
\text { Coordination (55) }\end{array}$ & \\
\hline
\end{tabular}

